\title{
SKEMA PEREKRUTAN MAHASISWA SEBAGAI TENAGA KERJA OUTSOURCING DALAM SEBUAH EVENT MICE (STUDI KASUS MAHASISWA POLITEKNIK NEGERI JAKARTA)
}

\author{
Yosi Erfinda \\ Program Studi MICE, Politeknik Negeri Jakarta \\ Email: yosi.erfinda@gmail.com
}

\begin{abstract}
As a business in service industries, event managemet and MICE depends on human resources. Many Professional Conference Organizer (PCO)/Professional Exhibition Organizer (PEO)/ Destination Management Company (DMC) recruit students majoring in MICE from the State Polytechnic of Jakarta ( PNJ) as outsource staffs in their event, which is beneficial for the company, students or PNJ as an institution. However some fundamental problems that can be identified from this practice, problems that occur due to recruiting system that has yet to be established well between companies and PNJ as a source of outsource staffs. This study aims to identify issues that have occurred from the current recruiting system and recommend a labor outsourcing system that can anticipate or solve issues that have been identified. Methods used in this study are: in-depth interview method and componential analysis.
\end{abstract}

Keywords: Outsourcing Scheme, MICE

\begin{abstract}
Abstrak
Aktivitas usaha perusahaan yang bergerak dalam Industri Jasa Pengelolaan Event/MICE, sangat bertumpu pada kompetensi sumber daya manusia di bidang Event/MICE. Banyaknya perusahaan PCO/PEO/DMC yang merekrut mahasiswa MICE Politeknik Negeri Jakarta (PNJ) sebagai tenaga Outsourcing dalam Event yang mereka kelola, merupakan sebuah keuntungan tersendiri bagi perusahaan maupun mahasiswa ataupun PNJ sebagai institusi. Namun terdapat permasalahan mendasar yang terlihat selama ini, dimana belum adanya sistem yang terjalin antara perusahaan sebagai pencari SDM dan PNJ sebagai penyedia SDM. Berdasarkan latar belakang tersebut, maka penelitian mengenai sebuah skema proses perekrutan mahasiswa sebagai sumber tenaga kerja Outsourcing event MICE menjadi sebuah hal yang penting untuk dilakukan. Penelitian ini ditujukan untuk mengidentifikasi masalah yang terjadi dari saat ini sistem perekrutan tenaga kerja dan merekomendasikan sistem outsourcing yang dapat mengantisipasi atau memecahkan persoalan yang telah diidentifikasi. Dalam mendukung penelitian ini, maka metode yang digunakan dalam penelitian ini diantaranya: Metode In-Depth Interview dan Analisis Komponensial (Componential Analysis).
\end{abstract}

Kata Kunci: Skema Outsourcing, MICE

\section{PENDAHULUAN}

Aktivitas usaha perusahaan yang bergerak dalam industri jasa pengelolaan Event/MICE (Meeting, Incentive, Convention and Exhibition) atau biasa dikategorikan sebagai Professional Conference Organizer (PCO); Professional Exhibition Organizer (PEO); maupun Destination Management Company (DMC), sangat bertumpu pada kompetensi sumber daya manusia di bidang Event/MICE. Seperti halnya, Destination Management Company (DMC) melalui program incentive travel ke destinasi pariwisata yang membutuhkan tenaga outsourcing. Pada program incentive travel tenaga outsourcing dibutuhkan untuk memastikan setiap kebutuhan amenities klien terpenuhi, sedangkan di bandara dibutuhkan 
tim ground handling untuk penjemputan dan pengantar klien dan serta tim advance (operasional) memastikan kebutuhan klien di destinasi tersebut.

Kemampuan perusahaan tersebut dalam merekrut sumber daya manusia yang professional akan menjadi suatu tantangan tersendiri. Dalam kondisi lain, nilai pendapatan dari jasa pengelolaan Event sangat bergantung dengan nilai proyek yang diperoleh, dimana siasat untuk menggunakan para pekerja lepas (Outsourcing) profesional yang mumpuni di bidang jasa pengelolaan Event/ MICE menjadi salah satu upaya yang selalu dilakukan. Hal tersebut tentunya sangat beralasan dimana, perusahaan harus seefektif mungkin mengontrol pengeluaran terutama mengenai pembiayaan tenaga kerja tetap. Kondisi ini didasari adanya fluktuasi pendapatan perusahaan, karena besarnya pendapatan sangat tergantung pada besaran nilai kontrak kerja jasa pengelolaan Event/ MICE yang dikerjakan.

Banyaknya perusahaan PCO/PEO/DMC yang merekrut mahasiswa MICE Politeknik Negeri Jakarta (PNJ) sebagai tenaga Outsourcing dalam Event yang mereka kelola, merupakan sebuah keuntungan tersendiri bagi perusahaan maupun mahasiswa ataupun PNJ sebagai institusi. Bagi perusahaan tentunya menjadi sebuah keuntungan memperoleh resource tenaga kerja yang paham tentang dunia Event/MICE sedangkan bagi Mahasiswa MICE PNJ dan Institusi PNJ, Event tersebut menjadi sebuah laboratorium kerja nyata bagi mahasiswa dan sebagai cara untuk mendekatkan diri kepada industri sebagai mitra yang tepat bagi Institusi PNJ.

Permasalahan mendasar yang terlihat selama ini adalah belum adanya sistem yang terjalin antara perusahaan sebagai pencari SDM dan PNJ sebagai penyedia SDM. Sistem yang dimaksud adalah terkait pola rekruitmen SDM Outsourcing yang efektif dan evaluasi yang berkala. Kedua hal tersebut akan sangat berpengaruh terhadap hubungan antara perusahaan $\mathrm{PCO} / \mathrm{PEO} / \mathrm{DMC}$ dengan Institusi PNJ kedepan. Tentunya dengan terbangunnya sistem yang baik, maka akan memberikan manfaat yang seimbang antar kedua belah pihak.

\section{Tujuan}

Tujuan dari penelitian ini adalah mengidentifikasi masalah yang terjadi dari saat ini sistem perekrutan tenaga kerja dan merekomendasikan sistem outsourcing yang dapat mengantisipasi atau memecahkan persoalan yang telah diidentifikasi dari perusahaan $\mathrm{PCO} /$ PEO/DMC sebagai mitra industri dan PNJ sebagai penyedia tenaga kerja, sehingga mempermudah perekrutan dan memberikan benefit yang sama antar kedua belah pihak. Penelitian ini sangat penting dilakukan karena dengan sistem model perekrutan dan evaluasi tenaga kerja Outsourcing antara perusahaan $\mathrm{PCO} / \mathrm{PEO} / \mathrm{DMC}$ sebagai mitra industri dan PNJ sebagai penyedia tenaga kerja, belum pernah dilakukan. Sehingga dengan adanya sistem model yang dikembangkan akan mempermudah perekrutan dan memberikan manfaat yang sama antar kedua belah pihak.

Tuntutan dari kemampuan perusahaan tersebut dalam merekrut sumber daya manusia yang professional menjadi hal-hal seringkali di luar kemampuan perusahaan baik kemampuan staf maupun kemampuan sumber daya. Sebagai hasilnya, timbullah Outsourcing, yaitu usaha untuk mengontrakkan suatu kegiatan pada pihak luar untuk memperoleh layanan pekerjaan yang dibutuhkan. Outsourcing, adalah alternatif dari melakukan pekerjaan sendiri. Tetapi Outsourcing tidak sekedar mengontrakkan secara biasa, tetapi jauh melebihi itu. Greaver II (2000) memberikan definisi Outsourcing sebagai berikut:

"Outsourcing is the act of transferring some of a company's recurring internal activities and decision rights to outside provider, as set forth in a contract. Because the activities are recurring and a contract is used, Outsourcing goes beyond 6the use of consultants. As a matter of practice, not only are the activities transferred, but the factors of production and decision rights often are, too. Factors of production are the resources that make the activities occur and include people, facilities, equipment, technology, and other assets. Decision rights are the responsibilities for making decisions over certain elements of the activities transferred." 
Garaventa dan Tellefsen (2001), memberikan definisi Outsourcing sebagai berikut ini.

Ousourcing dapat diartikan sebagai pengalihan alternatif fungsi tenaga kerja oleh sebuah organisasi dengan tujuan untuk mengurangi beban dan memperoleh sebuah keahlian teknis khusus, atau mencapai pengurangan biaya.

Event merupakan suatu peristiwa yang memerlukan beberapa orang untuk mengorganisimya. Sebuah perusahaan dapat mengggunakan event sebagai alat komunikasi untuk menyampaikan pesan produk maupun jasa dari perusahaannya. Seperti yang dikatakan O'Toole dan Mikolaitis (2002) mengatakan bahwa

Perusahaan menggunakan event sebagai sarana untuk berkomunikasi.

Pesan dalam event haruslah jelas demikian yang dikatakan Joe LoCICERO (2008):

Suatu event memiliki dampak yang paling luas dan perusahaan harus terlebih dahulu menentukan tujuannya. Sumber daya manusia dalam perusahaan harus memiliki tujuan jelas, tepat dan terikat dan dapat diukur.

Kalimat di atas bila diterjemahkan dapat memiliki arti bahwa membuat acara yang memiliki dampak paling luas, harus terlebih dahulu menentukan tujuannya. Tujuan dalam event tersebut harus jelas, tepat, terikat dalam beberapa cara untuk dapat mencapai tujuan perusahaan dan tentu saja harus bisa diukur. Pengukuran dapat dilakukan dengan mengadakan evaluasi terhadap pelaksanaan event.

Outsourcing adalah suatu bentuk strategi sumber daya manusia (human resource strategy) perusahaan, dimana untuk memenuhi kebutuhan sumber daya manusia perusahaan, perusahaan menggunakan dua jenis tenaga kerja yaitu: tenaga kerja tetap (tenaga kerja yang berasal dari dalam perusahaan) dan outsourcee (tenaga kerja yang berasal dari luar perusahaan/tenaga kerja kontrak). Tenaga kerja tetap berfungsi sebagai sumber daya manusia inti perusahaan sedangkan outsourcee berfungsi sebagai sumber daya manusia pelengkap yang jumlah dan waktu penggunaannya disesuaikan dengan kondisi yang sedang dihadapi perusahaan (Langford, 1995).

Outsourcee adalah yang bekerja pada perusahaan untuk melakukan pekerjaan tertentu dengan menerima upah, yang didasarkan atas kesepakatan dalam hubungan kerja untuk waktu tertentu dan atau selesainya pekerjaan tertentu (Tunggal, 2000), dimana kesepakatan kerja antara perusahaan dan outsourcee tersebut harus dinyatakan dalam bentuk tertulis (Kansil, 2001). Outsource yang dimaksud dalam studi ini tidak termasuk tenaga kerja harian lepas (tenaga kerja yang bekerja pada perusahaan untuk melakukan pekerjaan tertentu yang berubah-ubah dalam hal waktu maupun kontinuitas pekerjaan dengan menerima upah didasarkan atas kehadirannya secara harian) atau tenaga kerja borongan (tenaga kerja yang bekerja pada perusahaan untuk melakukan pekerjaan tertentu.

Rekrutmen menurut Hasibuan (2008) menyatakan bahwa proses rekrutmen merupakan usaha mencari dan mempengaruhi tenaga kerja, agar mau melamar lowongan pekerjaan yang ada dalam organisasi.

Proses rekrutmen menurut Mondy (2008) digambarkan dalam bagan di bawah ini.

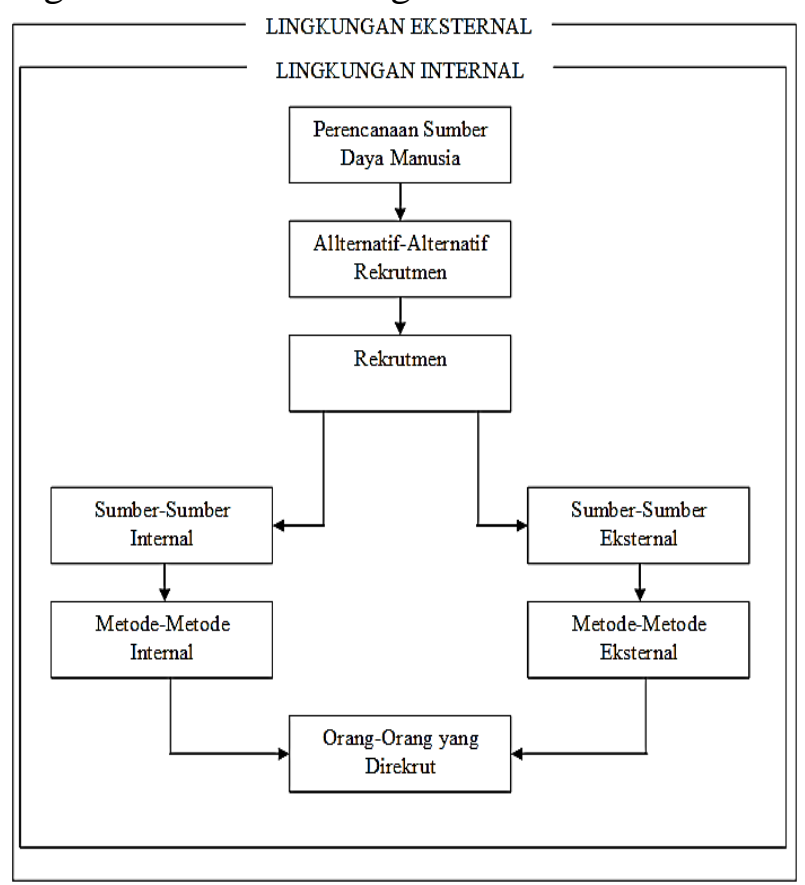

Gambar 1. Proses Rekrutmen (Mondy, 2008) 
Dapat disimpulkan dari gambar tersebut bahwa proses rekrutmen mencakup dua sumber yaitu sumber internal dan eksternal yang merupakan tempat di mana para kandidat yang memenuhi syarat berasal, yaitu perguruan tinggi dan perusahaan pesaing.

Tenaga kerja tetap adalah tenaga kerja yang bekerja pada perusahaan dengan waktu kerja penuh (full-time) serta memiliki suatu jenjang karir dalam struktur organisasi perusahaan. Tenaga kerja tetap ini merupakan bagian dari beban tetap yang harus ditanggung oleh perusahaan.

\section{METODE}

\section{Metode In-depth Interview}

Penelitian ini menggunakan teknik pengumpulan data berupa In-depth Interview yang dianalisis dengan Analisis Komponensial. Wawancara adalah merupakan pertemuan antara dua orang untuk bertukar informasi dan ide melalui tanya jawab sehingga dapat dikonstruksikan makna dalam suatu topik tertentu (Esterberg, 2002). Wawancara juga merupakan alat mengecek ulang atau pembuktian terhadap informasi atau keterangan yang diperoleh sebelumnya dan juga merupakan teknik komunikasi langsung antara peneliti dan responden.

Wawancara merupakan bagian dari metode kualitatif. Dalam metode kualitatif ini ada dikenal dengan teknik wawancara-mendalam (In-depth Interview). Pengertian wawancara-mendalam (In-depth Interview) adalah proses memperoleh keterangan untuk tujuan penelitian dengan cara tanya jawab sambil bertatap muka antara pewawancara dengan responden atau orang yang diwawancarai, dengan atau tanpa menggunakan pedoman (guide) wawancara dimana pewawancara dan informan terlibat dalam kehidupan sosial yang relatif lama (Sutopo 2006: 72). Ciri khusus dari wawancara-mendalam ini adalah keterlibatannya dalam kehidupan responden/informan.

Dalam wawancara-mendalam melakukan penggalian secara mendalam terhadap satu topik yang telah ditentukan (berdasarkan tujuan dan maksud diadakan wawancara tersebut) dengan menggunakan pertanyaan terbuka. Penggalian yang dilakukan untuk mengetahui pendapat mereka berdasarkan perspective responden dalam memandang sebuah permasalahan. Teknik wawancara ini dilakukan oleh seorang pewawancara dengan mewawancarai satu orang secara tatap muka (face to face). Target wawancara adalah 15 Perusahaan yang bergerak di bidang PCO/PEO/DMO dan berdomisili di Jakarta.

\section{Metode Analisis Komponensial}

Analisis komponensial merupakan metode penelitian kualitatif yang dikenalkan oleh Spradley (1980), dan Glaser dan Strauss (1967) yang mana secara garis besar model analisis ini diuraikan kedalam 4 model yaitu Analisis Domain (Domain analysis); Analisis Taksonomi (Taxonomy Analysis); Analisis Komponensial (Componential Analysis); dan Analisis Tema Kultural (Discovering Cultural Themes).

Dalam penelitian ini metode Analisis komponensial menjadi fokus utama yang dijadikan sebagai alat penelitian, untuk mampu menghasilkan sistem model perekrutan dan evaluasi terhadap outsourcing mahasiswa dalam kegiatan Event. Analisis komponensial dilakukan untuk mengorganisasikan perbedaan (kontras) antar unsur dalam ranah yang diperoleh melalui pengamatan dan atau wawancara terseleksi. Dalam hemat peneliti, kedalaman pemahaman tercermin dalam kemampuan untuk mengelompokkan dan merinci komponen dalam pembuatan model sistem perekrutan dan evaluasi.

1. Dengan mengetahui serta memahami kesamaan dan perbedaan antar kebutuhan kedua pihak dapat diperoleh pengertian menyeluruh dan mendalam serta rinci mengenai suatu pokok permasalahan. Dengan demikian akan diperoleh pemahaman makna dari masing-masing pihak secara holistik. Hasil lacakan kontras di antara pihak dimasukkan ke dalam lembar kerja paradigma (Spradley, 1979: 180). Kontras-kontras tersebut selalu diperiksa kembali sebagaimana dalam model analisis interaktif. Sehingga perlu dibuat ringkasan analisis komponensial, yang digunakan sebagai pemandu penulisan paparan hasil penelitian. Tahap akhir proses penelitian berupa menetapkan skema model yang sesuai dengan hasil yang diperoleh dengan cara observasi atau wawancara terfokus. 


\section{HASIL DAN PEMBAHASAN}

\section{Sistem Perekrutan Tenaga Outsourcing}

Sistem perekrutan tenaga outsourcing untuk event, dalam industri MICE yang peneliti temukan dalam proses penelitian diantaranya:

1. Sistem perekrutan melalui kerjasama lembaga pendidikan

2. Sistem perekrutan melalui kerjasama lembaga outsourcing

3. Sistem perekrutan melalui database dari Event sebelumnya

4. Sistem perekrutan melalui pertemanan dari pelaksana rekruitment

5. Sistem perekrutan berdasarkan rekomendasi dari tenaga rekrutmen

Hasil temuan mengenai sistem perekrutan yang umumnya dilakukan oleh perusahan, ditemukan dari hasil wawancara dengan beberapa pihak, salah satunya dengan Ayo Event selaku pelaksana untuk penyediaan tenaga outsourcing untuk event Food Ingredient Asia sejak tahun 2016 sampai sekarang. Salah satu catatan yang muncul dari wawancara dengan Anisa sebagai salah satu pemilik Ayo Event adalah sebagai berikut:

"Umumnya outsourcing event yang kami handle adalah perusahaan luar negeri yang akan menyelenggarakan Event di Indonesia. Hal tersebut dikarena mereka umumnya belum mengetahui kapasitas dari tenaga event di Indonesia. Sedangkan untuk perusahaan dalam negeri umumnya mereka mengajak mahasiswa dengan cara bekerjasama dengan salah satu kampus atau menggunakan tenaga outsourcing yang sudah pernah mereka gunakan"

Terdapat banyaknya sistem yang bias dilakukan oleh sebuah $P E O, P C O$ ataupun $D M C$ dalam melakukan perekrutan tenaga kerja, tentunya memberikan informasi yang beragam mengenai output yang dihasilkan dari masing tenaga kerja tersebut. Dimana pada akhirnya akan sangat berpengaruh kepada proses pelaksanaan event yang sebagian bebannya akan limpahkan kepada tenaga outsource tersebut. Kemampuan kerja dari masing-masing tenaga kerja yang dihasilan melalui sistem perekrutan menjadi suatu hal yang akhirnya kami telusuri lebih lanjut.

\section{Permasalahan yang Muncul}

Hasil penelitian juga menemukan bahwa dalam setiap sistem yang ditemukan oleh peneliti memiliki beberapa permasalahan yang umumnya muncul ketika proses recruitment dilaksanakan bahkan ketika para tenaga outsourcing telah menjalakan tugas yang diberikan. Permasalahan yang muncul diantaranya:

1. Sistem di institusi pendidikan tidak memungkinkan untuk melibatkan jumlah mahasiswa yang banyak sebagai tenaga outsourcing di waktu yang bersamaan.

2. Belum banyaknya tenaga outsourcing yang memiliki pemahaman yang sama terkait profesionalitas dalam bekerja.

3. Kapabilitas yang berbeda dari tenaga outsourcing ketika mereka dilibatkan berdasarkan rekomendasi tenaga outsourcing lain ataupun berdasarkan pertemanan dari staf pelaksana perekrutan.

4. Kesulitan menemukan pengganti ketika tenaga outsourcing yang dilibatkan tidak mampu bekerja dengan baik atau bahkan berhalangan.

5. Adanya ketidaksesuaian nilai yang dibayarkan dengan output yang diberikan oleh pekerja ataupun sebaliknya. Dengan menerima upah, yang didasarkan atas kesepakatan dalam hubungan kerja untuk waktu tertentu dan atau selesainya pekerjaan tertentu (Tunggal, 2000).

Permasalahan yang muncul tersebut peneliti temukan dari hasil wawancara kepada salah satu staf salah satu PCO di Indonesia yang mendapatkan tugas untuk melakukan reqruitment tenaga outsourcing.

"Terkadang perusahaan memiliki kesulitan untuk dapat menyesuaikan peraturan dari instansi pendidikan, dimana perusahaan membutuhkan jumlah tenaga outsourcing yang banyak dari instansi tersebut namun terbentur dengan ketentuan perkuliahan. Perusahaan bahkan harus mencari informasi dari tenaga outcoursing terdahulu untuk mendapatkan tenaga kerja, namun terkadang kemampuannya tidak sesuai dan dapat menjadi masalah bagi perusahaan dilapangan dan ketika itu perusahaan sulit untuk melakukan penggantian karena tidak adanya sistem yang mendukung." 
Sedangkan dari sisi tenaga outsourcing mereka juga mengalami kendala, terkait beban kerja yang tidak sesuai dengan pendapatan yang mereka peroleh. Hal tersebut terungkap dari salah satu narasumber kami, dimana beliau menyebutkan sebagai berikut:

"ketika diminta jadi outsourcing event kita terkadang selalu bertanya mengenai gaji yang diperoleh. Itu kita lakukan untuk mempertimbangkan, apakah kita terima atau tidak. Karena terkadang banyak $P C O, P E O$ dan DMC yang meminta kami terlibat tetapi pendapatan dan beban kerjanya tidak sesuai, boleh dikatakan kita agak prakmatis soal hal itu. Kami berpendapat, itu wajar karena kami punya pendidikan di background tersebut.

Tentunya berdasarkan temuan tersebut, dapat kita pahami terdapat persepsi dari dua sisi yang berbeda. Dimana pelaksana event berharap memperoleh pekerja dalam jumlah yang cukup dengan kapasitas yang baik, sedangkan tenaga kerja outsourcing memiliki motif terhadap pendapatan yang mereka peroleh (Tunggal, 2000).

\section{Skema Sistem perekrutan}

Kebutuhan akan sistem yang baik dalam proses perekrut tenaga kerja outsourcing menjadi salah satu tujuan dari penelitian ini, dimana dilapangan ditemukan bahwa dalam berbagai macam sistem yang telah ada memiliki banyak kendala yang harus ditemukan solusinya. Salah satunya adalah kemudahan untuk menemukan tenaga kerja yang mumpuni, dan mampu di ganti secara terstruktur ketika tidak mampu menjalankan tugasnya dilapangan. Selain itu adanya penilaian terhadap beban kerja dan pendapatan yang diberikan menjadi hal penting yang harus diperhatikan. Hal tersebut dibuktikan dengan adanya temuan bahwa, minat bekerja sangat bergantung pada pendapatan yang diperoleh. Untuk menemukan skema sistem perekrutan tersebut, peneliti mencoba memaparkan hasil temuan penelitian dalam wujud sebagai berikut: 1. Pelaksana Event harus memiliki skema kerja dan pendapatan yang jelas dan disesuaikan dengan beban kerja yang diberikan.
2. Kriteria tenaga kerja menjadi hal penting yang dibutuhkan, karena skill individu seorang tenaga outsourcing sangat berpengaruh terhadap output pekerjaan yang dihasilkan.

3. Pemahaman perektur, perusahaan outsourcing, teman terhadap skema kerja, kapasitas tenaga yang dibutuhkan dapat sangat membantu proses perekrutan.

4. Pembagian tenaga kerja dapat digolongkan berdasarkan kategori kemampuan, sehingga memudahkan para pelaksana event untuk menempatkan tenaga kerja yang tepat.

5. Kesepakatan kerja antara perusahaan dan outsourcee tersebut harus dinyatakan dalam bentuk tertulis (Kansil, 2001). Maka dari itu perlu adanya kontrak kerja dengan para pekerja, memberikan keleluasaan bagi setiap pihak untuk mengambil keputusan dan menjadikan pekerja tau kewajiban yang harus dilakukan (Kansil, 2001).

\section{KESIMPULAN}

Kesimpulan dalam penelitian adalah untuk menjawab seperti apa sistem perekrutan yang ada di Industri MICE Indonesia, Proses rekrutmen (Mondy, 2008) terdapat 2(dua) sumbser system internal dan eksternal dalam sistem perekrutan outsourcing di bidang MICE yang dapat dilakukan Perusahaan PCO/PEO/DMO yaitu:

\section{Sumber Internal:}

1. Sistem Perekrutan melalui kerjasama lembaga Pendidikan

2. Sistem Perekrutan melalui database dari Event sebelumnya

3. Sistem Perekrutan melalui pertemanan dari pelaksana rekruitment

\section{Sumber Eksternal:}

1. Sistem Perekrutan melalui kerjasama lembaga outsourcing

2. Sistem Perekrutan berdasarkan rekomendasi dari tenaga rekruitment

Dari kelima sistem tersebut ditemukan beberapa masalah yang terungkap diantaranya; adanya ketidaksesuaian waktu perekrutan dengan sistem perkuliahan; banyaknya tenaga kerja yang tidak memiliki pemahaman kerja yang baik; 
ataupun terkait pendapatan yang menjadi tolak ukur ketertarikan tenaga kerja untuk terlibat.

Skema yang dapat dilakukan untuk mengelola kondisi yang terungkap dalam hasil penelitian diantaranya sebagai berikut:

1. Pelaksana Event harus memiliki skema kerja dan pendapatan yang jelas dan disesuaikan dengan beban kerja yang diberikan.

2. Kriteria tenaga kerja menjadi hal penting yang dibutuhkan, karena skill individu seorang tenaga outsourcing sangat berpengaruh terhadap output pekerjaan yang dihasilkan.

3. Pemahaman perektur, perusahaan outsourcing, teman terhadap skema kerja, kapasitas tenaga yang dibutuhkan dapat sangat membantu proses perekrutan.

4. Pembagian tenaga kerja dapat digolongkan berdasarkan kategori kemampuan, sehingga memudahkan para pelaksana event untuk menempatkan tenaga kerja yang tepat.

Perlunya kontrak kerja dengan para pekerja, memberikan keleluasaan bagi setiap pihak untuk mengambil keputusan dan menjadikan pekerja tau kewajiban yang harus dilakukan.

\section{DAFTAR PUSTAKA}

Gainey, T. Klass, B. 2003. The Outsourcing of Training and Development: Factors Impacting Client Satisfaction, Journal of Management

Galanaki, E. Papalexandris, N. 2007, Internationalization as a determining factor of HRM outsourcing: Int. Journal of Human Resource Management
Ngo, Hang-Yue, Raymond Loi. 2008. Human resource flexibility, organizational culture and firm performance: an investigation of multinational firms in Hong Kong: The International Journal of Human Resource Management

O’Toole, William \& Mikolaitis, Phyllis .2002. Corporate Event Management. Project Management, New York.

Garaventa, Eugene \& Tellefsen, Thomas. 2001. Outsourcing: The Hidden Costs. Review of Business Journal, Vol 22, 2001.

Cicero, Joe Lo. 2008. Meeting and Event Planning, F \& W Publication, USA, 2008.

Stokes, R. 2004. A framework for the analysis of events-tourism knowledge networks. Journal of Hospitality and Tourism Management.

Sutadji. 2010. Perencanaan dan Pengembangan Sumber Daya Manusia. Dee Publish

Hariwijaya. 2017. Sukses Rekrutmen \& Seleksi Karyawan. Diandra Kreatif.

Marihot. 2002. Manajemen Sumber Daya Manusia: Pengadaan, Pengembangan, Pengkompensasian dan Peningkatan Produktivitas Pegawai. Grasindo.

Sulistyani Ambar T. Manajemen Sumber Daya Manusia, Penerbit Graha Ilmu. 2002

Sirait, Justine T.. Memahami Aspek-Aspek Pengelolaan Sumber Daya Manusia dalam Organisasi. Jakarta: Raja Grafindo. 2006 
Journal of Tourism Destination and Attraction 